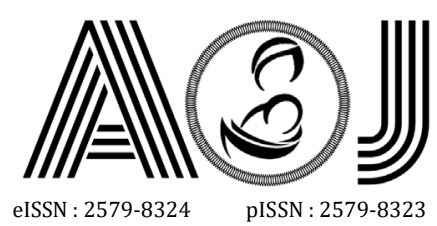

\title{
RESEARCH
}

\section{The Mean Difference of Hemostatic Factors in Severe Preeclampsia and Eclampsia}

Dyhan Purna Setia $^{1}$, Ferdinal Ferry ${ }^{2}$, Dovy Djanas ${ }^{3}$

Affiliations: 1. Resident of Obstetrics and Gynecology, Faculty of Medicine, Andalas University, Dr. M. Djamil Central General Hospital Padang; 2. Sub Division of Social Obstetrics and Gynecology, Obstetrics and Gynecology Department, Faculty of Medicine, Andalas University, Dr. M. Djamil Central General Hospital Padang; 3. Sub Division of Maternal Fetal Medicine, Obstetrics and Gynecology Department, Faculty of Medicine, Andalas University, Dr. M. Djamil Central General Hospital Padang

Correspondence: Dyhan Purna Setia, email: dyhan_p@yahoo.com, Hp: 082384896660

\section{Abstract}

The aim of this study was to see the difference in the mean ratio of sodium levels between pregnancy with severe preeclampsia and eclampsia. The method in this research is an analytical study using a cross sectional design. The research was conducted in the delivery room Dr. M. Djamil Padang from 15 January 2016 to 31 December 2017. There were 60 patients as research subjects, the sample was divided into 2 groups, namely severe preeclampsia (PEB) and eclampsia. Anamnesis and physical examination were then carried out to obtain data and clinical diagnosis. The data were recorded in a research form that had been provided, then the blood electrolytes were examined for sodium and potassium. Statistical analysis to assess meaning using the T-test. The results showed that in the PEB and Eclampsia groups, it was found that multiparity parity had the highest respondents. This is in accordance with the literature where the incidence of preeclampsia is more often found at gestational age near term. The conclusion of this study there was no significant difference in the mean sodium ratio between preeclampsia, PEB and eclampsia.

Keywords: pregnancy condition, PEB, eclampsia, platelet, PT, APTT, and D-Dimer

\section{INTRODUCTION}

Preeclampsia is defined as a condition of hypertension and proteinuria after gestational age 20 weeks. Preeclampsia is a major pregnancy complication whose incidence is increasing worldwide and is associated with maternal morbidity and mortality. ${ }^{19,20}$ Preeclampsia and eclampsia are the cause of $30-40 \%$ of perinatal deaths in Indonesia. ${ }^{1}$ In Indonesia the incidence rate ranges from 7-10\%. Research conducted by RSUP Dr. M. Djamil Padang in 2012 - 2013. The number of patients with preeclampsia who were treated and recorded in the medical records of Dr. RSUP M. Djamil Padang in 2012 there were 193 people from 1,682 deliveries and in 2013 there were 206 people from 1,714 deliveries. ${ }^{2}$ During the period of January 1, 2005 to December 31, 2007 at BLU Dr. M. Djamil Padang found 220 patients (4.99\%) with severe preeclampsia and 47 eclampsia (1.07\%) from 4407 deliveries. $^{3}$ Preeclampsia can be bad for both mother and fetus. Worsening of the course of the disease 


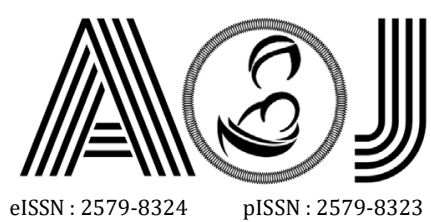

eISSN : 2579-8324
pISSN : 2579-8323

Ruang Redaksi Andalas Obstetrics and Gynecology Journal, Lantai 3 PPDS Obstetri dan Ginekologi Universitas Andalas, RSUP DR. M. Djamil Padang, Jl. Perintis Kemerdekaan Padang, Sumatera Barat 25127

in the mother can be in the form of eclampsia, HELLP Syndrome, pulmonary edema, kidney failure, DIC, hypertensive crisis, and encephalopathy hypertension while in the fetus can be in the form of premature birth, fetal distress, low birth weight, intra uterine fetal death (IUFD) ${ }^{4,5} \mathrm{~A}$ collection of symptoms of preeclampsia associated with vasospasm, increased peripheral vascular resistance, and decreased organ perfusion. Abnormalities in the form of vascular lesions occur in many organ systems including the placenta, there is also an increase in platelet activation and activation of the coagulation system. ${ }^{6}$ Preeclampsia is an obstetrical condition that is most often associated with activation of blood clotting cascades that produce fibrin deposits in many organs. ${ }^{7}$ In the process of blood clotting there are three mechanisms of hemostasis, namely primary hemostasis, secondary hemostasis and fibrinolysis. In primary hemostasis the role is the platelet plug in endothelial blood vessels that have been injured. Whereas secondary hemostasis occurs in the formation of fibrin clot through intrinsic and extrinsic pathways. Only then will the fibrinolysis process occur to prevent ongoing freezing. ${ }^{8,9}$

In the hematological and coagulation systems, preeclampsia is associated with a coagulation abnormality complex associated with improved function of platelets, activation of the fibrinolytic system, thrombin formation and accelerated hypercoagulation. Meanwhile, women with minimal preeclampsia have some evidence of disturbance or abnormality from the blood clotting cascade. ${ }^{10}$

In severe preeclampsia or eclampsia, one of the acute worsening of life to the mother and baby is coagulopathy or disseminated intravascular coagulapathy (DIC). DIC is a hematological disorder in which the clotting process occurs along with the occurrence of bleeding due to fibronolysis. Because in DIC there is progressive coagulopathy and conditions, so early diagnosis, treatment and appropriate management are needed to reduce maternal and infant mortality and other complications. ${ }^{11}$

\section{METHOD}

This research is a descriptive analytic study with cross sectional study design. This research was conducted by looking at the prospective medical record status of subjects in accordance with the time and place of research. The study was conducted in the medical record of RSUP. Dr. M. Djamil Padang starts from 15 January 2016 - 31 December 2017. Secondary data were collected from medical records in the Medical Record Section of RSUP. Dr. M. Djamil Padang with independent variables Thrombocyte levels, PT, APTT and D-Dimer. The dependent variable is the incidence of preeclampsia and eclampsia. Data processing in this study uses the SPSS (Statistical package of Social Science) version 16.0 program which was analyzed by T-Test. 


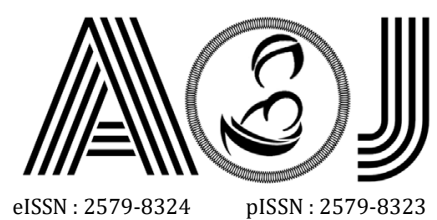

eISSN : 2579-8324
pISSN : 2579-8323

Ruang Redaksi Andalas Obstetrics and Gynecology Journal, Lantai 3 PPDS Obstetri dan Ginekologi Universitas Andalas, RSUP DR. M. Djamil Padang, Jl. Perintis Kemerdekaan Padang, Sumatera Barat 25127

http://jurnalobgin.fk.unand.ac.id/index.php/JOE

\section{RESULTS AND DISCUSSION}

Of the 60 samples that met the inclusion criteria studied, the following study subjects' characteristics were obtained. In the PEB pregnancy group and eclampsia, the mean age was $29.41 \pm 3.93$ years and $28.57 \pm 5.11$. In the PEB and Eclampsia groups, multipara parity respondents had the highest respondents (66.67\% and $76.2 \%)$. Preterm gestational age had high respondents in the PEB and Eclampsia groups (61.53\% and 66.67\%). The average platelet according to the condition of pregnancy can be seen in table 2 . The tendency is that the more severe the condition of pregnancy the further the number of platelets decreases; the difference was statistically significant $(p<0.05)$.

Table 1 Distribution of Respondent Characteristics

\begin{tabular}{cccc}
\hline & & Severe Preeclampsia & Eclampsia \\
& & $\mathrm{n}=39$ & $\mathrm{n}=21$ \\
\hline Age & & $29.41 \pm 3.93$ & $28.57 \pm 5.11$ \\
Parity & Nulipara & $13(33.33 \%)$ & $5(23.8 \%)$ \\
& Multipara & $26(66.67 \%)$ & $16(76.2 \%)$ \\
\multirow{3}{*}{ Gestational age } & Preterm & $24(61.53 \%)$ & $14(66.67 \%)$ \\
& term & $15(38.47 \%)$ & $7(33.33 \%)$ \\
\hline
\end{tabular}

Table 2 Average Platelets according to Pregnancy Conditions

\begin{tabular}{cccc}
\hline Pregnancy Conditions & Mean $(\mathbf{s b})$ & p-value & Mean Difference (IK95\%) \\
\hline $\begin{array}{c}\text { Severe Preeclampsia }(\mathbf{n}=\mathbf{3 9}) \\
\text { Eclampsia }(\mathbf{n}=\mathbf{2 1})\end{array}$ & $\begin{array}{l}204717,1(105929,954) \\
112571.43(26452,953)\end{array}$ & \multirow{2}{*}{0,000} & 92146,52 \\
\hline *independent sample t-test & & & $(56082,93-128210,1)$ \\
\hline
\end{tabular}

*independent sample t-test

The mean prothrombin time (PT) according to pregnancy conditions can be seen in table 3. There is a tendency that the more severe the condition of pregnancy the lower the mean PT value, but statistically the difference is not significant $(p>0.05)$.

Table 3 Average PT according to pregnancy conditions

\begin{tabular}{cccc}
\hline Pregnancy Conditions & Mean $(\mathbf{s b})$ & p-value & Mean Difference (IK95\%) \\
\hline Severe Preeclampsia $(\mathbf{n}=\mathbf{3 9})$ & $9.30(1,236)$ & 0,374 & $0.319(-0.399-1,037)$ \\
Eclampsia $(\mathbf{n}=\mathbf{2 1})$ & $8.98(1,349)$ & & \\
\hline
\end{tabular}

* independent sample t-test

The mean value of Activated Protrombin Time (APTT) according to the condition of pregnancy can be seen in table 4, the more severe the condition of pregnancy the higher the mean APTT value, statistically the difference is not significant ( $p>0.05)$. 


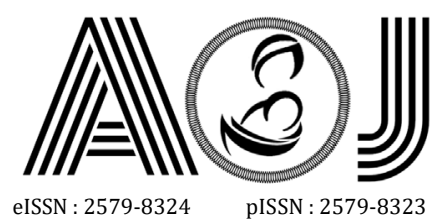

eISSN : 2579-8324
pISSN : 2579-8323

Ruang Redaksi Andalas Obstetrics and Gynecology Journal, Lantai 3 PPDS Obstetri dan Ginekologi Universitas Andalas, RSUP DR. M. Djamil Padang, Jl. Perintis Kemerdekaan Padang, Sumatera Barat 25127

Website:

http://jurnalobgin.fk.unand.ac.id/index.php/JOE

Table 4 Average Activated Protrombin Time (APTT) according to pregnancy condition

\begin{tabular}{cccc}
\hline Pregnancy Conditions & Mean $(\mathbf{s b})$ & p-value & Mean Difference (IK95\%) \\
\hline $\begin{array}{c}\text { Severe Preeclampsia }(\mathbf{n}=\mathbf{3 9}) \\
\text { Eclampsia }(\mathbf{n}=\mathbf{2 1})\end{array}$ & $\begin{array}{l}32.07(6,697) \\
33.15(3,159)\end{array}$ & 0,401 & \multirow{2}{*}{$1,275(-3,63-1,47)$} \\
\hline *
\end{tabular}

*independent sample t-test

Average D-Dimer levels according to the conditions of pregnancy can be seen in Table 5 The more severe the conditions of pregnancy the higher the mean D-Dimer value, statistically the difference is not significant $(p>0.0)$.

Table 5 Average D-Dimer Value according to Pregnancy Conditions

\begin{tabular}{cccc}
\hline Pregnancy Conditions & Mean $(\mathbf{s b})$ & p-value & Mean Difference (IK95\%) \\
\hline $\begin{array}{c}\text { Severe Preeclampsia }(\mathbf{n}=\mathbf{3 9}) \\
\text { Eclampsia }(\mathbf{n}=\mathbf{2 1})\end{array}$ & $\begin{array}{c}2967.93(1768.50) \\
4031.47(2436.77)\end{array}$ & 0.09 & $-1063,54(-22910,285-164,204)$ \\
\hline
\end{tabular}

* independent sample t-test

\section{DISCUSSION}

The more severe the condition of pregnancy the decreasing mean platelet count based on the T-Test was statistically significant $(p<0.05)$. According to the literature it is stated that the reduction in the number of platelets in preeclampsia is related to endothelial damage in all blood vessels where platelets are used as the primary mechanism of the hemostasis system. ${ }^{4}$ The disruption process of hemostasis can cause multiple organ failure, where the activation of massive clotting factors can cause a decrease in the number platelets and coagulation factors resulting in bleeding / consumption coagulopathy.

The more severe the condition of pregnancy the shorter the mean PT value, but statistically the difference was not significant $(p>0.05)$. PT is part of the mechanism of secondary hemostasis through extrinsic pathways where endothelial damage continues to occur in patients preeclampsia will trigger activation of the pathway, in the early stages it will be seen as a tendency for the shortened PT value. Activation of the extrinsic pathway is triggered by trauma to the tissue structure or to the walls of blood vessels. ${ }^{6}$ So it can be concluded that there is a relevance between the severity of the pregnancy condition and the degree of endothelial damage.

The mean APTT value shows that the more severe the condition of pregnancy, the higher the APTT mean value, statistically the difference is not significant $(p>0.05)$. Endothelial damage in preeclampsia that occurs will lead to activation of the intrinsic pathway which will be seen as an elongated APTT value. APTT values vary according to the severity of the progression of preeclampsia itself and may be prolonged in the final process when the clotting factor drops very low. ${ }^{7}$ 


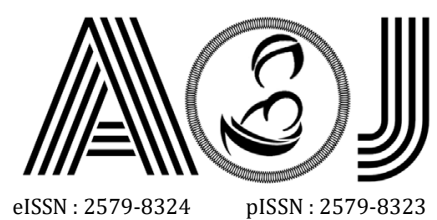

eISSN : 2579-8324
pISSN : 2579-8323

Ruang Redaksi Andalas Obstetrics and Gynecology Journal, Lantai 3 PPDS Obstetri dan Ginekologi Universitas Andalas, RSUP DR. M. Djamil Padang, Jl. Perintis Kemerdekaan Padang, Sumatera Barat 25127

The more severe the pregnancy condition, the higher the D-Dimer mean value, statistically the difference was not significant $(p<0.05)$. This increase in D-Dimer is a picture of the amount of thrombus that occurs due to the process of fibrinolysis to control so that coagulation activity is not excessive, Plasmin causes degradation of fibrin, increases the amount of dissolved fibrin degradation products, high levels indicate the presence of a lot of thrombus in the blood. ${ }^{8}$

\section{CONCLUSION}

In this study it can be concluded that there is a tendency to decrease the average platelet count based on the increasingly severe pregnancy conditions which are statistically significant, there is a tendency to shorten the mean PT value based on the severity of the pregnancy conditions but statistically not significant. The mean value of APTT with pregnancy conditions was not significant between PEB and eclampsia and the mean D-Dimer level in PEB with eclampsia was statistically not significant.

\section{REFERENCES}

1. Cunningham, F.G et al. William Obstetrics 24nd. Pregnancy Hypertension. The McGraw-Hill Companies, Inc. New York; 2014. 706-756

2. Roeshadi HR. Hipertensi dalam kehamilan. Dalam : Ilmu kedokteran fetomaternal. Ed pertama. Himpunan Kedokteran Fetomaternal Perkumpulan Obstetri dan Ginekologi Indonesia. Surabaya, 2004: 494-500.

3. Sibai, Baha M. Diagnosis and Management of Gestational Hypertension and Preeclampsia. The American College of Obstetricians and Gynecologists Vol 102 No 1. Elsevier; July 2003

4. Baskett T. Disseminated Intravascular Coagulation (DIC) in Pregnancy. 2010.

5. Levi M. Disseminated Intravascular Coagulation (DIC) in Pregnancy and the Peripartum Period. Department of Internal Medicine, Academic Medical Center, University of Amsterdam. Dalam: Trombosis Research 123 Suppl.2. The Netherlands: 2009. 563-4.

6. Stewart C. Disseminated Intravascular Coagulation (DIC). Australia Critical Care 2001; 14(2): 71-75

7. Widjaja, AC. Uji Diagnostik Pemeriksaan Kadar D-Dimer Plasma Pada Diagnosis Stroke Iskemik. Bagian Patologi Klinik Fakultas Kedokteran Universitas Diponegoro. Semarang: 2010

8. Denantika O, Serudji J, Revilla G, Hubungan Status Gravida dan Usia Ibu terhadap Kejadian Preeklampsia di RSUP Dr. M. Djamil Padang Tahun 2012-2013, Jurnal Kesehatan Andalas. 2015; 4(1):212-7 


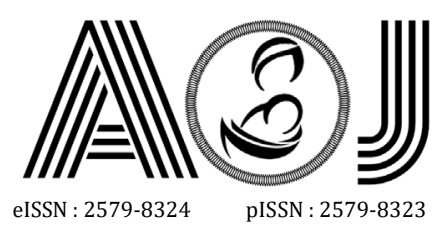

eISSN : 2579-832

Ruang Redaksi Andalas Obstetrics and Gynecology Journal, Lantai 3 PPDS Obstetri dan Ginekologi Universitas Andalas, RSUP DR. M. Djamil Padang, Jl. Perintis Kemerdekaan Padang, Sumatera Barat 25127

Website:

http://jurnalobgin.fk.unand.ac.id/index.php/JOE

9. Madi J, Sulin. D. Angka kematian Pasien preeklampsia dan Eklampsia RS Dr M Djamil padang tahun 1998-2002. Bagian Obstetri dan Ginekologi FK Unand/RS Dr. M. Djamil. Padang.

10. Wiknjosastro, H. Ilmu Kebidanan. Yayasan Bina Pustaka Sarwono Prawirohardjo. Jakarta; 2008

11. Erez O, Novack L, Beer-Weisel R, Dukler D, Press F, et al. (2014) DIC Score in Pregnant Women - A Population Based Modification of the International Society on Thrombosis and Hemostasis Score. PLoS ONE 9(4): 